\title{
THE INSTITUTIONAL ENVIRONMENT FOR ECONOMIC GROWTH
}

\author{
WITOLD J. HENISZ*ं
}

\begin{abstract}
This article forges an explicit link between an objective measure of political constraints and variation in cross-national growth rates. It derives a new measure of political constraints from a simple spatial model of political interaction that incorporates information on the number of independent branches of government with veto power and the distribution of preferences across and within those branches. The derived variable is found to have a statistically and economically significant impact on growth rates using simple ordinary least squares, three-stage least squares and generalized method of moments estimation techniques.
\end{abstract}

\section{INTRODUCTION}

DESPITE A flurry of recent activity, the link between theoretical arguments for a government's ability to provide a credible commitment to the returns to private property and the empirical literature on the economic impacts of such political institutions remains incomplete. Papers aiming to test for the existence of this relationship in areas as disparate as macroeconomic growth, international business and industrial organization have recently converged upon the use of institutional variables constructed by the International Country Risk Guide (ICRG). These indexes measure the rule of law, the likelihood of government expropriation, the likelihood of government contract repudiation, the extent of government corruption and the bureaucratic competence of a given country. The fact that private sector investment decisions are influenced by private sector perceptions of such economic outcomes does not, by itself, establish the inferred link between investment and political institutions. This article aims to forge that link by demonstrating that the feasibility of change in policy as derived from a structural model of political interaction is a robust determinant of cross-national variation in economic growth.

\footnotetext{
*This paper is an edited version of Chapter 2 of my dissertation: "The Institutional Environment for International Investment: Safeguarding Against State Sector Opportunism and Opportunistic Use of the State". Funding for this paper was generously provided by the Bradley and Olin Foundations, the Joe Shoong Chair of International Business and the Institute for Management, Innovation and Organization. I would like to thank Oliver Williamson, Pablo Spiller, Henry Brady, Pat Moreton, Kyle Mayer, Bennet Zelner, Robert Powell, J. Bradford De Long, and seminar participants at UC Berkeley for their comments on previous drafts.

${ }^{\dagger}$ Correspondence to: Witold J. Henisz, The Wharton School, University of Pennsylvania, 2021 Steinberg Hall - Dietrich Hall, Philadelphia, PA 19104-6370, USA.

E-mail: henisz@wharton.upenn.edu
} 
Theoretical support for the economic impact of political institutions has expanded dramatically in the quarter century since North and Thomas (1973) first outlined a "transaction cost view of economic history". The crucial economic role played by socio-political factors which reduce the costs of bargaining, contracting, monitoring and enforcement has achieved the status of conventional wisdom not only in economic history [e.g. North (1990) and Weingast (1993)] but also in economic development [e.g. Borner et al. (1995), Olson (1996) and The World Bank (1997)]. Each of the above authors reach the conclusion that a government's ability to credibly commit not to interfere with private property rights is instrumental in obtaining the long-term capital investments required for countries to experience rapid economic growth.

More formal modelling efforts that capture the centrality of credible commitments have recently expanded beyond the literature on central bank reform and industrial organization to that of economic policy. Several formal positive political models incorporating the objectives and incentives of policy-makers and the constraints on their actions have recently been advanced within the development field [e.g. Dornbusch (1991), Murphy et al. (1991), Rodrik (1992, 1993)]. Each modelled the disparate impact of credible and non-credible reforms and demonstrated that a lack of credibility would undermine stabilization programs, postpone adjustment to trade reform, postpone investment, depress savings, encourage capital flight and promote the growth of the black market economy.

Both the transaction cost theory of economic history and these more formal economic modelling efforts allow for two direct channels through which the institutional environment affects macroeconomic outcomes. First, frequent and potentially arbitrary changes in taxation, regulatory or other relevant economic policy increase investor uncertainty and raise hurdle rates for private investment. In response to this hazard, investors may choose to either invest in safeguards against policy changes, demand higher and more immediate returns, or alter the nature of their investments - to include not investing at all. These effects will be strongest for large sunk investments whose returns are spread over an extended period such as infrastructure or new technology. These are precisely the types of investments typically identified by economists and policy-makers as central to the development process. Second, institutional environments in which economic returns can easily be secured through political channels lead individuals to reallocate resources from economic to political activity. While the former is value enhancing, the latter is more often characterized, at best, as a zero-sum game. Both of these channels lead to lower and less economically productive investment and, therefore, lower rates of economic growth. ${ }^{1}$

Published articles that test these hypotheses in a rigorous manner (a broad sample of countries over a decade or more of time with tests for robustness) have

\footnotetext{
${ }^{1} \mathrm{~A}$ third indirect channel not addressed in this paper links institutional development to the transaction costs of exchange between private counterparties and the relative efficacy of various modes of economic organization or governance.
} 
appeared only in the past few years. They generally adopt one of three types of measurement of the institutional environment. First, measures such as the Gastil indexes attempt to quantify the degree of democracy or political and civil liberties in a country. As Knack and Keefer (1995) argue, these measures need not be correlated with the degree of commitment to private property rights. Chronically unstable democracies in which power alternates between parties with strongly divergent policies and stable autocracies with long time horizons that operate under the rule of law are clear examples in which the correlation breaks down in an important way.

Second, political instability measures, such as counts of assassinations or revolutions, do perform more consistently than political or civil rights measures. However, the results are weakened as the sample size grows to include more autocratic regimes in which the stability of weak property rights is provided.

Finally, the indexes compiled by the ICRG and others attempt to quantify the degree of country risk faced by multinationals. This is a broader question that includes, but is not limited to, the analysis of credible commitment. Furthermore, it relies on subjective measures that are not closely linked to political institutions and that are available for only the past 15 years. These limitations call into question the exogeneity of the measures, reduce the potential power of the tests and invite questions regarding sample selection. Nevertheless, several recently published papers all obtain results that support the claim that these measures are correlated with international variation in private investment and growth [e.g. Knack and Keefer (1995), Mauro (1995), Clague et al. (1996), Barro (1996), Sala-i-Martin (1997) and Keefer and Knack (1997)].

While data exists on political institutions for a substantially greater time period, the difficulty in improving upon country risk measures is in identifying which objectively measurable political institutions matter and how various measures should be combined. Campos and Nugent (1996) undertake principal component analysis on eight measures from the Polity database ${ }^{2}$ [see Gurr (1996)] and find that the derived institutional variable is a significant determinant of cross-national variation in growth in a sample of Latin American countries. La Porta et al. (1997) show that the historical origin of corporate law (British, French, Spanish or Dutch) predicts variation in the development and deepness of financial markets across countries. Durham (1999) finds that the number of effective parties is not a significant predictor of growth or investment.

The extant empirical measures thus suffer from some combination of four faults. First, many of them are not closely linked to a government's ability to credibly commit not to interfere with private property rights. Second, they are subjectively measured. Third, they are available only for limited time periods and/or samples of countries. Finally, they are often employed in an atheoretical

\footnotetext{
${ }^{2}$ Competitiveness of executive recruitment, openness of executive recruitment, constraints on the executive, competitiveness of participation, regulation of participation, legislative effectiveness, legislative selection, and limitations on the scope of government action.
} 
manner. This article seeks to develop a measure of institutional commitment that is subject to less criticism on each of these counts. It draws from recent theoretical developments in positive political theory to develop a structurally derived and internationally comparable measure of the degree of constraints on policy change using data on the number of independent veto points in the political system (executive, legislative, judicial and sub-federal branches of government) and the distribution of political preferences both across and within these branches.

Of course, the constraints provided by these institutional and political factors may also hamstring government efforts to respond to external shocks and/or to correct policy mistakes. ${ }^{3}$ German labor market reform and Brazilian fiscal reform are clear examples in which the presence of checks and balances on the discretion of policy-makers leads to excessive inertia and the "lock-in" of bad policies. However, the assumption in the literature and in this article is that, on average, the benefits of constraints on executive discretion outweigh the costs of lost flexibility. While the extant empirical literature supports this assumption, the empirical results presented here provide an additional test as to whether, on average, constraints on the discretion of political actors in the policy realm offer net gains or losses to a country's economy. The questions of the determinants of good or bad status quo policies and the conditions under which flexibility is relatively more or less costly, while of fundamental importance to economic welfare, are left for future research. The conclusion to this paper offers some preliminary speculation regarding the mechanism by which the modelling framework offered here may be extended to incorporate such potential determinants of good (or bad) policy and the costs (or benefits) of flexibility as electoral rules and institutions that lead to more particularistic policies.

\section{A NEW MEASURE OF CREDIBLE COMMITMENT}

\subsection{Modelling Approach}

This paper draws upon the theoretical foundations of work in positive political theory that employs spatial modelling frameworks in order to demonstrate that policy outcomes are a function of political structure. With relatively few exceptions [e.g. Moe and Caldwell (1994), Palmer (1995), Spiller and Vogelsang (1996) and Baron (1998)] both theoretical and empirical work in this domain has been set in the context of the American political system beginning with the committee structure of the US Congress, extending to the analysis of executive agency decision-making and, more recently, including the Presidency and judiciary as independent political actors. This paper seeks to expand the empirical use of this analytical framework in the international context beyond the qualitative approach adopted by Levy and Spiller (1994) to quantify

\footnotetext{
${ }^{3}$ Thanks to Andrei Shleifer, Susan Rose Ackerman and an anonymous referee for highlighting this point.
} 
variation in the ability of political institutions to provide a credible commitment to private property rights across a wide sample of countries and across time. As in Levy and Spiller (1994) and the extant literature reviewed in the introduction, I assume that the feasibility of policy change produces uncertainty and lower levels of investment and growth. As in the positive political theory literature, rather than describe the credibility of a given political structure, I adopt a simple spatial model of political interaction to derive it.

In order to construct a structurally-derived internationally comparable measure of political constraints, the structure of political systems must be simplified in a manner which allows for cross-national comparisons in as many as 157 countries while retaining the elements of that structure which have a strong bearing on the feasibility of policy change. Here, I will focus on two such elements: the number of independent veto points over policy outcomes and the distribution of preferences of the actors that inhabit them. Without minimizing their importance, I set aside questions of agenda-setting power, decision costs [see Spiller and Tiller (1997)] and the relative political authority held by various institutions for subsequent extensions of the admittedly simplistic modelling framework presented here.

Political actors will be denoted by $E$ (for executive), $L 1$ (for lower house of legislature), $L 2$ (for upper house of legislature), $F$ (for sub-federal units) and $J$ (for judiciary). Each political actor has a preference, denoted by $X_{\mathrm{I}}$ where $I \in[E, L 1, L 2, F, J]$. Assume, initially, that the status quo policy $\left(X_{0}\right)$ and the preferences of all actors are independently and identically drawn from a uniformly distributed unidimensional policy space $[0,1]$. The utility of political actor $I$ from a policy outcome $X$ is assumed equal to $-\left|X-X_{\mathrm{I}}\right|$ and thus ranges from a maximum of 0 (when $X=X_{\mathrm{I}}$ ) to a minimum of -1 (when $X=0$ and $X_{\mathrm{I}}=1$ or vice versa). Further assume that each actor has veto power over final policy decisions. While these are, admittedly, strong assumptions, the incorporation of more refined and realistic game structures and preference distributions presents severe complications for analytic tractability. It is hoped that, mirroring the development of the positive political theory literature domestically, the strength of the results obtained using the simple framework presented here will provide an impetus for future research.

The variable of interest to investors in this model is the extent to which a given political actor ${ }^{4}$ is constrained in his or her choice of future policies. This variable is calculated as one minus the expected range of policies for which a change in the status quo can be agreed upon by all political actors with veto power. For example, regardless of the status quo policy, an unchecked executive can always

\footnotetext{
${ }^{4}$ Without loss of generality, the remainder of the paper refers to changes in executive preferences. Note that since the preferences of all actors and the status quo policy are drawn identically from the same distribution, each actor, including the executive, faces the same constraints in changing policy. Allowance for the likelihood of multiple actors changing preferences simultaneously is made by incorporating information on alignment of preferences across the various branches of government later in the analysis.
} 
obtain policy $X_{E}$ and is guaranteed their maximum possible utility of 0 . Investors face a high degree of uncertainty since the executive's preferences may change or the executive may be replaced by another executive with vastly different preferences. I therefore categorize this as a polar case in which political discretion equals 1 and political constraints $(1-$ political discretion $)=0$.

As the number of actors with independent veto power increases, the level of political constraints increases. For example, in a country with an effective unicameral legislature $(L 1)$, the executive must obtain the approval of a majority of the legislature in order to implement policy changes. The executive is no longer guaranteed the policy $X_{E}$ as the legislature may veto a change from the status quo policy. The executive can, at best, achieve the outcome closest to $X_{E}$ that is preferred by the legislature to the status quo. Without additional information on the preferences of the executive and the legislature it is impossible to compute the exact outcome of the game. Nor is the expected magnitude of the effect on political discretion of adding this additional veto point immediately clear. However, one of the virtues of the simple spatial model outlined above is that it provides a more objective insight into the quantitative significance of adding an additional veto point.

Given the assumption that preferences are drawn independently and identically from a uniform distribution, the expected difference between the preferences of any two actors can be expressed as $1 /(n+2)^{5}$ where $n$ is the number of actors. Assuming that there exist two political institutions with veto power [the executive $(E)$ and a unicameral legislature $(L 1)$ ], the initial preference draw yields an expected preference difference equal to $1 /(2+2)=1 / 4$. There are six possible preference orderings in this game (see Figure 1) that I will assume are equally likely to occur in practice. ${ }^{6}$

In ordering (1), no change in executive preferences that retains the initial ordering of preferences yields a change in policy. The executive $\left(X_{E}=1 / 4\right)$ prefers all policies between $1 / 2-\varepsilon$ and $0+\varepsilon$ to the status quo $\left(X_{0}=1 / 2\right)$ while the legislature $\left(X_{L 1}=3 / 4\right)$ prefers all policies between $1 / 2+\varepsilon$ and $1-\varepsilon$ to $X_{0}$. As the executive and the legislature cannot agree on a change in policy, political discretion (the feasibility of policy change) equals 0 and political constraints equal 1. The same argument is true by symmetry for ordering (2). In the remaining orderings, both the executive and legislature agree on a direction in which policy should move relative to the status quo $X_{0}$. These cases have closedform solutions other than the status quo policy. Their exact values depend on the assumption as to who moves first (or last) and the relative costs of review by each party.

However, in the absence of knowledge on the rules of the game in each country, the range of outcomes over which both parties can agree to change the

\footnotetext{
${ }^{5}$ See Rice (1995, p. 155).

${ }^{6}$ For expositional convenience, I center each of the preference distributions on the unit line. As long as the expected difference between any two preferred points remains $1 / 4$, the quantitative results are insensitive to the absolute location of these points.
} 
(1)

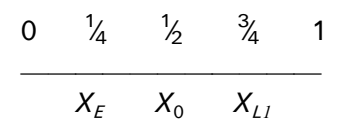

EEEEEEEEEE

LLLLLLLLL

(2)

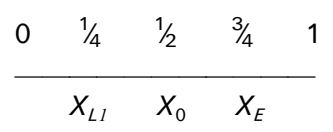

LLLLLLLLLL

(3)

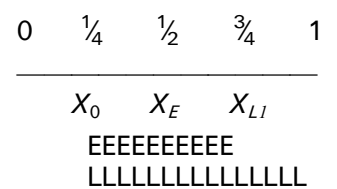

(4)

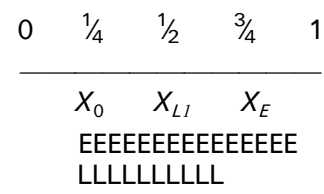

(5)

\begin{tabular}{ccccc}
0 & $1 / 4$ & $1 / 2$ & $3 / 4$ & 1 \\
\hline & $X_{E}$ & $X_{L 1}$ & $X_{0}$ \\
EEEEEEEEEEEEEEEE \\
LLLLLLLLLLL
\end{tabular}

(6)

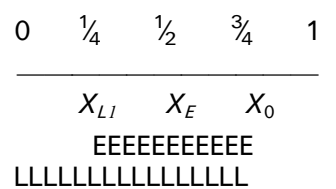

Note: $E$ indicates the range of outcomes preferred by the executive to the status quo $X_{0}$. $L$ indicates the range of outcomes preferred by the legislature to the status quo $X_{0}$.

Figure 1. The six possible preference ordering of the game $\left\{X_{E}, X_{L l}\right\}$.

status quo is used as a measure of political discretion. As this range expands, there exists a larger set of policy changes preferred by both political actors with veto power. The existence of such a set reduces the credibility of any given policy. In ordering (3), the executive $\left(X_{E}=1 / 2\right)$ prefers policies between $1 / 4+\varepsilon$ and $3 / 4-\varepsilon$ to the status quo $\left(X_{0}=1 / 4\right)$ while the legislature $\left(X_{L 1}=3 / 4\right)$ prefers all policies greater than $1 / 4+\varepsilon$. There exists a range of policies approximately equal to $1 / 2$ (between $1 / 4+\varepsilon$ and $3 / 4-\varepsilon$ ), which both actors agree are superior to the status quo. The political discretion measure for this ordering therefore equals $1 / 2$ yielding a political constraint measure also equal to $1 / 2$. The same is true in orderings (4), (5) and (6). The expected level of political constraints for the game $\left\{X_{E}, X_{L 1}\right\}$ based on the number of veto points alone is the average of the political constraint measures across the six possible preference orderings: $(1+1+1 / 2+1 / 2+1 / 2+1 / 2) / 6=2 / 3$.

Note that this measure of political constraints is based solely on the number of de jure veto points in a given polity maintaining the strong and unrealistic assumption of uniformly distributed preferences. However, neither the Constitutional existence of veto power nor its prior exercise provide a de facto veto threat in the current period. Specifically, alignment (i.e., majority control of the executive and the legislature by the same party) would be expected to expand the range of political discretion and thereby reduce the level of political constraints. In order to allow for this effect, the purely institutional measure of political constraints described above is supplemented with 
Table 1 Political Constraints Assuming Complete IndePendence or Alignment

\begin{tabular}{|c|c|c|c|c|c|c|}
\hline \multirow{2}{*}{$\begin{array}{l}\text { Independent } \\
\text { political actors }\end{array}$} & \multicolumn{6}{|c|}{ Entities completely aligned with executive } \\
\hline & None & $L^{\mathrm{a}}$ & $J$ & $L 1 \& L 2$ & $L \& J$ & $L 1 \& L 2 \& J$ \\
\hline$E$ & 0 & & & & & \\
\hline$E, L 1$ & $2 / 3$ & 0 & & & & \\
\hline$E, F$ & $2 / 3$ & & & & & \\
\hline$E, J$ & $2 / 3$ & & 0 & & & \\
\hline$E, L 1, F$ & $4 / 5$ & $2 / 3$ & & & & \\
\hline$E, L 1, L 2$ & $4 / 5$ & $2 / 3$ & & 0 & & \\
\hline$E, L 1, J$ & $4 / 5$ & $2 / 3$ & $2 / 3$ & & 0 & \\
\hline$E, L 1, L 2, F$ & $13 / 15$ & $4 / 5$ & & $2 / 3$ & & \\
\hline$E, L 1, F, J$ & $13 / 15$ & $4 / 5$ & $4 / 5$ & & $2 / 3$ & \\
\hline$E, L 1, L 2, J$ & $13 / 15$ & $4 / 5$ & $4 / 5$ & $2 / 3$ & $2 / 3$ & 0 \\
\hline$E, L 1, L 2, F, J$ & $19 / 21$ & $13 / 15$ & $13 / 15$ & $4 / 5$ & $4 / 5$ & $2 / 3$ \\
\hline
\end{tabular}

Notes: $E=$ executive, $L 1=$ lower legislature, $L 2=$ upper legislature, $F=$ sub-federal, $J=$ judiciary. ${ }^{\text {a }}$ Either $L 1$ or $L 2$.

information on the preferences of various actors. For example, if the legislature were completely aligned with the executive, the game would revert back to our simple unitary actor discussed above with a constraint measure of 0 . The same exercise of determining constraints given the assumption of either completely independent or completely aligned actors was conducted for all observed institutional structures yielding the values for political constraints displayed in Table 1.

Further modifications are required when other political actors are neither completely aligned with nor completely independent from the executive. In these cases, the party composition of the other branches of government are also relevant to the level of constraints. For example, if the party controlling the executive enjoys a majority in the legislature, the level of constraints is negatively correlated with the magnitude and concentration of that majority. Aligned legislatures with large homogeneous majorities are less costly to manage and control than aligned legislatures with precarious majorities that are highly heterogeneous and/or polarized.

By contrast, when the executive is faced with an opposition legislature, the level of constraints is positively correlated with the magnitude and concentration of the legislative majority. A heavily fractionalized opposition with a precarious majority may provide the executive with a lower level of constraints due to the difficulty in forming a cohesive legislative opposition bloc to any given policy. Information on the partisan alignment of different government branches and on the difficulty of forming a majority coalition within them can therefore provide valuable information as to the extent of political constraints. 
Suppose, for example, that the party controlling the executive completely controls the other branch(es) of government $\left(100 \%^{7}\right.$ of legislative seats or supreme court justices). In this case, the values displayed in the appropriate right-hand column of Table 1 are utilized. However, as the executive's need for coalition building and maintenance increases (his or her majority diminishes), and under the assumption that the same party controls both branches, the values converge to the levels displayed in the left-most column. For the case in which the branches are controlled by different parties, the results are reversed. Now, complete concentration by the opposition ( $100 \%$ of legislative seats or supreme court justices) leads to the assignment of the values in the left-most column. As the opposition's difficulty of forming coalitions increases, the values converge to the levels displayed in the appropriate right-hand column. Following an extensive body of literature in political science on the costs of forming and maintaining coalitions, the rate of convergence is based upon the extent of legislative (or judicial) fractionalization (Rae and Taylor, 1970).

The fractionalization of the legislature (or court) is approximately equal to the probability that two random draws from the legislature or court are from different parties. The exact formula is:

$$
1-\sum_{i=1}^{n}\left[\frac{\left(n_{i}-1\right) \frac{n_{i}}{N}}{N-1}\right]
$$

where $n=$ the number of parties, $n_{i}=$ the number of seats held by $i$ th party and $N=$ the total number of seats. The final value of political constraints for cases in which the executive is aligned with the legislature(s) and/or court is thus equal to the value derived under complete alignment plus the fractionalization index multiplied by the difference between the independent and completely aligned values calculated above. For cases in which the executive's party is in the minority in the legislature(s) and/or courts, the modified constraint measure equals the value derived under complete alignment plus (one minus the fractionalization index) multiplied by the difference between the completely independent and aligned values calculated above. In cases of mixed alignment, a weighted (equally) sum of the relevant adjustments is used.

For example, in the case described above the constraint measure equalled 0 if the legislature was completely aligned and $2 / 3$ if it was completely independent. However, if the same party controls the executive and the legislative chamber and the fractionalization index equals $1 / 4$ (the executive has a large and/or homogeneous majority in Parliament) then the modified constraint measure equals $0+1 / 4 *(2 / 3-0)=1 / 6$. By contrast, if the fractionalization index equals $3 / 4$ (the executive's majority is very precarious and/or heterogeneous), the

\footnotetext{
${ }^{7}$ I assume that as the majority diminishes from this absolute level the difficulty in satisfying the preferences of all coalition or faction members increases thus increasing the level of political constraints.
} 
modified constraint measure would equal $0+3 / 4 *(2 / 3-0)=1 / 2$. In the case where the opposition controls the legislature the values would be reversed. A large and/or homogeneous opposition majority would lead to a value of $0+(1-1 / 4) *(2 / 3-0)=1 / 2$ while a small and/or heterogeneous opposition legislature would yield a score of $0+(1-3 / 4) *(2 / 3)=1 / 6$. Appendix 1 provides a more detailed description of the data and methodology used in the construction of the political constraint measure as well as a set of sample calculations.

These calculations were undertaken for as many as 157 countries in every year from 1960 to 1994. The average values of political constraints (POLCON and $P O L C O N J$ ) for each country in each five-year period are displayed in Table $2 .^{8}$ The results for $P O L C O N J$ show that the most credible institutional environments are found in early defectors from the British Empire (the United States, Australia and Canada) and federal European states (Belgium and Germany). The countries with the highest hazards are Cameroon, Kenya, Malawi, Paraguay, Sudan and Zambia. Expanding the sample by assuming that all judiciaries are in opposition $(P O L C O N)$ demonstrates that there exist many countries with as few constraints on executive discretion as evidenced even in these countries.

Further perspective can be gained by examining the time trend of these variables. From 1960 to 1994, the largest improvements in POLCON were recorded by countries undergoing democratic transitions in Latin America, Asia and Eastern Europe. Notable deteriorations in scores were recorded only by Burundi, Chile (under Pinochet), Guyana, Jamaica (1985-1989), Lebanon, Nigeria, Panama, the Philippines (under Marcos), Sierra Leone, Sri Lanka, Somalia and Uruguay. Country rankings in POLCONJ followed a similar trend.

These scores align closely with our intuition as to the level of and change in political hazards in these countries. Furthermore, the measures are strongly correlated with the ICRG risk indexes $(0.78$ for POLCON and 0.64 for $P O L C O N J)$ and the Polity executive constraint index $(0.71$ and 0.71 respectively). Interestingly, one of the regions where the correlation breaks down in an important way is South and East Asia which are scored quite highly (strong constraints on the executive and low country risk) by both Polity and ICRG but due to the lack of formal veto points, strongly aligned and homogeneous legislatures and subservient court systems scored quite low on POLCON. ${ }^{9}$ Recent events in these countries lend credence to the values assigned by the methodology described in this paper relative to extant measures.

\footnotetext{
${ }^{8}$ As described in Appendix 1, POLCON and POLCONJ differ in that the latter uses actual data on the appointment history of High Court justices to compute the alignment and fractionalization of the High Court. As this data is currently available for only 44 countries, POLCON which assumes that all courts characterized as effective veto points (see Appendix for definition) are completely independent from the executive and legislature(s) was also calculated.

${ }^{9}$ The 1994 scores for Korea, Thailand, Malaysia and Indonesia were 7, 4, 7 and 2 by Polity (out of a maximum of 7 with a 1994 mean of 4.8); 7, 6, 6, 6 by ICRG (out of a maximum of 7 with a 1994 mean of 4.1 ) and $0.41,0.34,0.13$ and 0.00 by POLCON (out of a maximum of 1 with a 1994 mean of 0.35 ).
} 
The strong positive correlation of these three measures over the postwar period indicates that, despite their different methodologies, the three measures track the same underlying phenomenon: the quality of political institutions. However, the relative objectivity of the political constraint measures derived in this paper may offer some advantages to the more experience-based measures in times of rapid institutional change. Specifically, rather than await for improvements in the expropriation, contract repudiation, corruption, bureaucratic efficiency, and law and order records of a given country $(I C R G)$ or evidence that the executive is, in fact, constrained in policy-making by other political institutions (POLITY), the methodology used in this paper examines the structure of the political system and assesses the likelihood that future government policy will be constrained. Observation of the institutional transitions in Peru, the Philippines, South Africa and South Korea support this hypothesis as $P O L C O N$ values shifted in the year of the transition in all cases while POLITY and ICRG scores shifted with a lag of up to five years or not at all (see Figure 2).

Future research will attempt to improve the forecastability of policy change by adding data on the alignment of federalist entities; more microanalytic detail on rule-making and veto power among branches of government; and membership, participation or recognition in/of certain international organizations or standards to the simple game structure used here. In an attempt to justify such further research, a test of the economic power of this simplified political measure will be conducted using the well-developed methodology employed in the macroeconomic growth literature.

\section{TESTS OF THE PROPOSED MEASURE}

\subsection{The Determinants of Growth}

Beginning with Solow (1956), a vast theoretical and empirical literature has attempted to address the question

Is there some action a government like India could take that would lead the Indian economy to grow like Indonesia or Egypt's? If so, what exactly? If not, what is it about the 'nature of India' that makes it so?

(Lucas, 1988, p. 5)

A primary theoretical result from this extensive literature is the notion of conditional convergence: ceteris paribus, poor countries should be expected to grow faster. This result derives [see Mankiw et al. (1992)] from the assumption of diminishing marginal returns to capital in a country's production function. Put simply, laggard countries could, if they enjoyed all the characteristics of the wealthiest countries except their income level, grow much faster than leaders due to the higher marginal return on their relatively small capital stock. Much of the empirical work has attempted to identify the correct array of choice 
Table 2 Average 1960-1994 Values for Politcal Constraint IndeXes for 157 Countries

Country name

'60-64 '65-69 '70-74 '75-79 '80-84'85-89 '90-94 '60-64'65-69 '70-74'75-79'80-84'85-89 '90-94

POLCON

POLCONJ

\begin{tabular}{lccccccc}
\hline Afghanistan & 0.00 & 0.00 & 0.00 & 0.00 & 0.00 & 0.00 & 0.00 \\
Albania & 0.00 & 0.00 & 0.00 & 0.00 & 0.00 & 0.00 & 0.43 \\
Algeria & 0.00 & 0.00 & 0.00 & 0.00 & 0.00 & 0.00 & 0.00 \\
Angola & & & & 0.00 & 0.00 & 0.00 & 0.19 \\
Argentina & 0.00 & 0.00 & 0.00 & 0.00 & 0.07 & 0.38 & 0.48 \\
Armenia & & & & & & & 0.59 \\
Australia & 0.86 & 0.86 & 0.86 & 0.86 & 0.86 & 0.87 & 0.85 \\
Austria & 0.78 & 0.77 & 0.78 & 0.78 & 0.78 & 0.78 & 0.79 \\
Azerbaijan & & & & & & & 0.00 \\
Bahrain & & & 0.00 & 0.00 & 0.00 & 0.00 & 0.00 \\
Bangladesh & & & 0.02 & 0.00 & 0.00 & 0.00 & 0.35 \\
Belarus & & & & & & & 0.00 \\
Belgium & 0.86 & 0.87 & 0.88 & 0.88 & 0.86 & 0.88 & 0.86 \\
Benin & 0.00 & 0.00 & 0.00 & 0.00 & 0.00 & 0.00 & 0.13 \\
Bhutan & 0.00 & 0.00 & 0.00 & 0.00 & 0.00 & 0.00 & 0.00 \\
Bolivia & 0.09 & 0.00 & 0.00 & 0.00 & 0.10 & 0.33 & 0.21 \\
Botswana & & 0.69 & 0.72 & 0.71 & 0.69 & 0.70 & 0.70 \\
Brazil & 0.77 & 0.67 & 0.67 & 0.67 & 0.67 & 0.85 & 0.82 \\
Bulgaria & 0.00 & 0.00 & 0.00 & 0.00 & 0.00 & 0.00 & 0.73 \\
Burkina Faso & 0.00 & 0.00 & 0.00 & 0.00 & 0.00 & 0.00 & 0.00 \\
Burma & 0.11 & 0.00 & 0.00 & 0.00 & 0.00 & 0.00 & 0.00 \\
Burundi & 0.25 & 0.00 & 0.00 & 0.00 & 0.00 & 0.00 & 0.00 \\
Cambodia & 0.00 & 0.00 & 0.00 & 0.00 & 0.00 & 0.00 & 0.08 \\
Cameroon & 0.00 & 0.00 & 0.00 & 0.00 & 0.00 & 0.00 & 0.16 \\
Canada & 0.85 & 0.86 & 0.85 & 0.85 & 0.86 & 0.85 & 0.85 \\
& & & & & &
\end{tabular}

\begin{tabular}{|c|c|c|c|c|c|c|}
\hline 0.00 & 0.00 & 0.00 & 0.00 & 0.07 & 0.38 & 0.48 \\
\hline \multirow[t]{2}{*}{0.80} & 0.78 & 0.79 & 0.80 & 0.80 & 0.81 & 0.77 \\
\hline & & & 0.00 & 0.00 & 0.00 & 0.35 \\
\hline 0.78 & 0.79 & 0.81 & 0.82 & 0.80 & 0.81 & 0.77 \\
\hline & & 0.36 & 0.12 & 0.07 & 0.11 & \\
\hline 0.62 & 0.67 & 0.67 & 0.67 & 0.27 & 0.76 & 0.74 \\
\hline 0.00 & 0.00 & 0.00 & 0.00 & 0.00 & 0.00 & 0.00 \\
\hline 0.79 & 0.79 & 0.79 & 0.78 & 0.79 & 0.79 & 0.77 \\
\hline
\end{tabular}




\begin{tabular}{|c|c|c|c|c|c|c|c|c|c|c|c|c|c|c|c|}
\hline Central African Republic & 0.00 & 0.00 & 0.00 & 0.00 & 0.00 & 0.00 & 0.11 & & & & & & & & \\
\hline Chad & 0.00 & 0.00 & 0.00 & 0.00 & 0.00 & 0.00 & 0.00 & & & & & & & & \\
\hline Chile & 0.70 & 0.80 & 0.45 & 0.00 & 0.00 & 0.00 & 0.77 & 0.18 & 0.44 & 0.19 & 0.00 & 0.00 & 0.00 & 0.30 & \\
\hline China, PR & 0.00 & 0.00 & 0.00 & 0.00 & 0.00 & 0.00 & 0.00 & & & & & & & & \\
\hline Colombia & 0.40 & 0.41 & 0.30 & 0.43 & 0.40 & 0.43 & 0.44 & 0.40 & 0.41 & 0.30 & 0.43 & 0.40 & 0.43 & 0.44 & \\
\hline Comoros & & & & 0.00 & 0.00 & 0.00 & 0.00 & & & & & & & & \\
\hline Congo & 0.00 & 0.00 & 0.00 & 0.00 & 0.00 & 0.00 & 0.20 & & & & & & & & \\
\hline Costa Rica & 0.73 & 0.74 & 0.74 & 0.76 & 0.75 & 0.74 & 0.68 & & & & & & & & \\
\hline Côte d'Ivoire & 0.00 & 0.00 & 0.00 & 0.00 & 0.00 & 0.00 & 0.00 & & & & & & & & \\
\hline Croatia & & & & & & & 0.44 & & & & & & & & \\
\hline Cuba & 0.13 & 0.00 & 0.00 & 0.00 & 0.00 & 0.00 & 0.00 & & & & & & & & $\leq$ \\
\hline Cyprus & 0.00 & 0.00 & 0.00 & 0.26 & 0.26 & 0.18 & 0.24 & & & & & & & & $\bar{\pi}$ \\
\hline Czech Republic & & & & & & & 0.81 & & & & & & & & z \\
\hline Czechoslovakia & 0.00 & 0.13 & 0.00 & 0.00 & 0.00 & 0.00 & 0.87 & & & & & & & & 3 \\
\hline Denmark & 0.76 & 0.77 & 0.77 & 0.78 & 0.78 & 0.78 & 0.77 & & & & & & & & 荤 \\
\hline Dominican Republic & 0.00 & 0.19 & 0.35 & 0.18 & 0.41 & 0.44 & 0.48 & 0.00 & & 0.35 & 0.18 & 0.41 & & & \\
\hline Ecuador & 0.00 & 0.00 & 0.00 & 0.13 & 0.73 & 0.72 & 0.70 & & 0.00 & 0.00 & 0.00 & 0.42 & & & $\stackrel{T}{0}$ \\
\hline Egypt & 0.00 & 0.00 & 0.00 & 0.00 & 0.00 & 0.00 & 0.00 & & & & & & & & \\
\hline El Salvador & 0.00 & 0.22 & 0.37 & 0.30 & 0.19 & 0.40 & 0.43 & & & & & & & & $\pi$ \\
\hline Ethiopia & 0.00 & 0.00 & 0.00 & 0.00 & 0.00 & 0.00 & 0.00 & & & & & & & & $\sum$ \\
\hline Finland & 0.77 & 0.77 & 0.78 & 0.78 & 0.78 & 0.77 & 0.78 & & & & & & & & $\exists$ \\
\hline France & 0.63 & 0.65 & 0.79 & 0.80 & 0.78 & 0.76 & 0.80 & 0.63 & 0.57 & 0.50 & 0.50 & 0.45 & 0.41 & 0.47 & \\
\hline Gabon & 0.00 & 0.00 & 0.00 & 0.00 & 0.00 & 0.00 & 0.00 & & & & & & & & \\
\hline Gambia, The & & 0.16 & 0.22 & 0.16 & 0.21 & 0.22 & 0.17 & & & & & & & & \\
\hline Georgia & & & & & & & 0.00 & & & & & & & & \\
\hline Germany, DR & 0.00 & 0.00 & 0.00 & 0.00 & 0.00 & 0.00 & 0.00 & & & & & & & & \\
\hline Germany, FR & 0.83 & 0.83 & 0.84 & 0.83 & 0.83 & 0.83 & 0.83 & 0.72 & 0.72 & 0.77 & 0.75 & 0.74 & 0.76 & 0.73 & \\
\hline Ghana & 0.00 & 0.00 & 0.13 & 0.00 & 0.09 & 0.00 & 0.00 & 0.00 & 0.00 & 0.13 & 0.00 & 0.09 & 0.00 & 0.00 & \\
\hline Greece & 0.38 & 0.14 & 0.00 & 0.33 & 0.36 & 0.36 & 0.38 & & & & & & & & \\
\hline Guatemala & 0.00 & 0.00 & 0.00 & 0.00 & 0.00 & 0.32 & 0.44 & 0.00 & 0.00 & 0.00 & & 0.00 & 0.22 & & \\
\hline
\end{tabular}




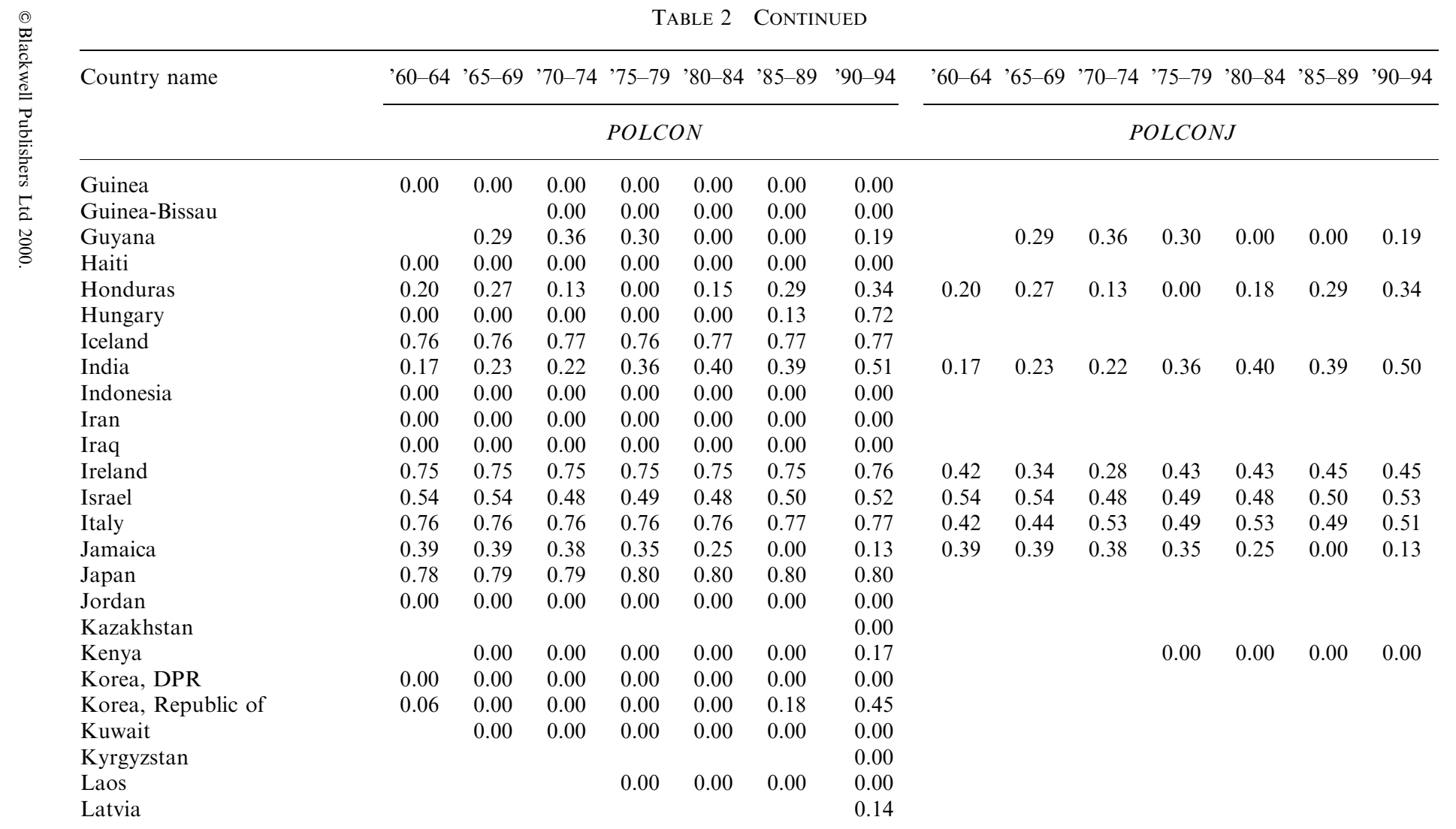




\begin{tabular}{|c|c|c|c|c|c|c|}
\hline Lebanon & 0.55 & 0.55 & 0.38 & 0.12 & 0.07 & 0.00 \\
\hline Lesotho & & 0.24 & 0.00 & 0.00 & 0.00 & 0.00 \\
\hline Liberia & 0.00 & 0.00 & 0.00 & 0.00 & 0.00 & 0.00 \\
\hline Libya & 0.00 & 0.00 & 0.00 & 0.00 & 0.00 & 0.00 \\
\hline Lithuania & & & & & & \\
\hline Luxembourg & 0.76 & 0.76 & 0.76 & 0.77 & 0.76 & 0.76 \\
\hline Macedonia & & & & & & \\
\hline Madagascar & 0.70 & 0.17 & 0.01 & 0.00 & 0.00 & 0.00 \\
\hline Malawi & & 0.00 & 0.00 & 0.00 & 0.00 & 0.00 \\
\hline Malaysia & 0.72 & 0.56 & 0.58 & 0.69 & 0.70 & 0.70 \\
\hline Mali & 0.00 & 0.00 & 0.00 & 0.00 & 0.00 & 0.00 \\
\hline Mauritania & 0.00 & 0.00 & 0.00 & 0.00 & 0.00 & 0.00 \\
\hline Mauritius & & 0.44 & 0.44 & 0.34 & 0.30 & 0.37 \\
\hline Mexico & 0.04 & 0.10 & 0.11 & 0.13 & 0.18 & 0.19 \\
\hline Moldova & & & & & & \\
\hline Mongolia & 0.00 & 0.00 & 0.00 & 0.00 & 0.00 & 0.00 \\
\hline Morocco & 0.00 & 0.00 & 0.00 & 0.00 & 0.00 & 0.00 \\
\hline Mozambique & & & & 0.00 & 0.00 & 0.00 \\
\hline Namibia & & & & & & \\
\hline Nepal & 0.00 & 0.00 & 0.00 & 0.00 & 0.00 & 0.00 \\
\hline Netherlands & 0.82 & 0.83 & 0.84 & 0.83 & 0.82 & 0.82 \\
\hline New Zealand & 0.73 & 0.74 & 0.73 & 0.73 & 0.74 & 0.73 \\
\hline Nicaragua & 0.00 & 0.00 & 0.00 & 0.00 & 0.00 & 0.00 \\
\hline Niger & 0.00 & 0.00 & 0.00 & 0.00 & 0.00 & 0.00 \\
\hline Nigeria & 0.43 & 0.08 & 0.00 & 0.00 & 0.30 & 0.00 \\
\hline Norway & 0.76 & 0.76 & 0.76 & 0.76 & 0.76 & 0.76 \\
\hline Oman & 0.00 & 0.00 & 0.00 & 0.00 & 0.00 & 0.00 \\
\hline Pakistan & 0.00 & 0.13 & 0.00 & 0.00 & 0.00 & 0.14 \\
\hline Panama & 0.28 & 0.15 & 0.00 & 0.00 & 0.00 & 0.00 \\
\hline Papua New Guinea & & & & 0.83 & 0.85 & 0.85 \\
\hline
\end{tabular}

0.24

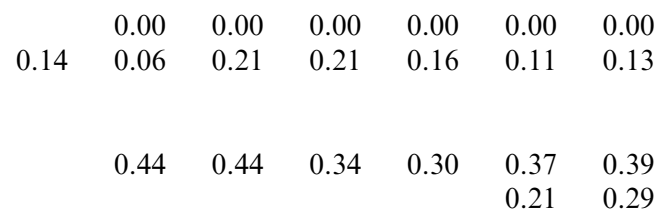

$\begin{array}{lllllll}0.61 & 0.58 & 0.57 & 0.56 & 0.62 & 0.57 & 0.52\end{array}$

$\begin{array}{lllllll}0.39 & 0.36 & 0.35 & 0.34 & 0.30 & 0.38 & 0.37\end{array}$

$\begin{array}{lllllll}0.00 & 0.00 & 0.00 & 0.00 & 0.00 & 0.00 & 0.36\end{array}$

$\begin{array}{lllllll}0.43 & 0.08 & 0.00 & 0.00 & 0.30 & 0.00 & 0.00\end{array}$

$\begin{array}{lllllll}0.27 & 0.32 & 0.45 & 0.42 & 0.37 & 0.34 & 0.39\end{array}$

$\begin{array}{lllllll}0.00 & 0.00 & 0.00 & 0.00 & 0.00 & 0.14 & 0.39\end{array}$

Continued 
Country name

POLCON

Paraguay

Peru

Philippines

Poland

Portugal

Romania

Russia

Rwanda

Saudi Arabia

Senegal

Sierra Leone

Singapore

Slovakia

Slovenia

Somalia

South Africa

Soviet Union

Spain

Sri Lanka

Sudan

Swaziland

Sweden

Switzerland

Syria

Taiwan
'60-64 '65-69 '70-74 '75-79' 80-84 '85-89 '90-94

'60-64 '65-69 '70-74 '75-79'80-84'85-89' '90-94

POLCONJ

$\begin{array}{llllllllllllll}0.00 & 0.00 & 0.00 & 0.00 & 0.00 & 0.00 & 0.09 & 0.00 & 0.00 & 0.00 & 0.00 & 0.00 & 0.00 & 0.00 \\ 0.23 & 0.11 & 0.00 & 0.00 & 0.00 & 0.31 & 0.12 & 0.23 & 0.11 & 0.00 & 0.00 & & & 0.05 \\ 0.39 & 0.41 & 0.13 & 0.00 & 0.00 & 0.10 & 0.40 & 0.39 & 0.41 & 0.13 & 0.00 & 0.00 & 0.13 & 0.40 \\ 0.00 & 0.00 & 0.00 & 0.00 & 0.00 & 0.13 & 0.71 & & & & & & & \\ 0.00 & 0.00 & 0.13 & 0.74 & 0.75 & 0.76 & 0.74 & & & & & & & \\ 0.00 & 0.00 & 0.00 & 0.00 & 0.00 & 0.00 & 0.31 & & & & & & & \\ & & & & & & 0.01 & & & & & & & \\ 0.00 & 0.00 & 0.00 & 0.00 & 0.00 & 0.00 & 0.00 & & & & & & & \\ 0.00 & 0.00 & 0.00 & 0.00 & 0.00 & 0.00 & 0.00 & & & & & & & \\ 0.00 & 0.00 & 0.00 & 0.00 & 0.00 & 0.00 & 0.00 & & & & & & \end{array}$

$\begin{array}{llllll}0.35 & 0.27 & 0.01 & 0.00 & 0.00 & 0.00\end{array}$

0.76

$\begin{array}{llllll}0.24 & 0.00 & 0.00 & 0.01 & 0.03 & 0.02\end{array}$

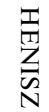

$\begin{array}{lllllll}0.00 & 0.35 & 0.00 & 0.00 & 0.00 & 0.00 & 0.00 \\ 0.26 & 0.31 & 0.32 & 0.32 & 0.24 & 0.23 & 0.42\end{array}$

$\begin{array}{lllllll}0.00 & 0.00 & 0.00 & 0.00 & 0.00 & 0.00 & 0.00\end{array}$

$\begin{array}{lllllll}0.00 & 0.00 & 0.00 & 0.72 & 0.79 & 0.78 & 0.80\end{array}$

$\begin{array}{lllllll}0.28 & 0.51 & 0.44 & 0.32 & 0.20 & 0.20 & 0.40\end{array}$

$\begin{array}{lllllll}0.00 & 0.37 & 0.00 & 0.00 & 0.00 & 0.00 & 0.00\end{array}$

$\begin{array}{llllll}0.00 & 0.00 & 0.00 & 0.00 & 0.00 & 0.00\end{array}$

$\begin{array}{lllllll}0.76 & 0.76 & 0.76 & 0.76 & 0.76 & 0.76 & 0.77\end{array}$

$\begin{array}{lllllll}0.86 & 0.86 & 0.86 & 0.88 & 0.88 & 0.86 & 0.87\end{array}$

$\begin{array}{lllllll}0.00 & 0.00 & 0.00 & 0.00 & 0.00 & 0.00 & 0.00\end{array}$

$\begin{array}{lllllll}0.00 & 0.00 & 0.00 & 0.22 & 0.19 & 0.19 & 0.62\end{array}$ $\begin{array}{lllllll}0.26 & 0.31 & 0.32 & 0.32 & 0.24 & 0.23 & 0.42\end{array}$

$\begin{array}{lllllll}0.28 & 0.51 & 0.44 & 0.32 & 0.20 & 0.20 & 0.40\end{array}$

$\begin{array}{llllll}0.00 & 0.00 & 0.00 & 0.00 & 0.00 & 0.00\end{array}$ 


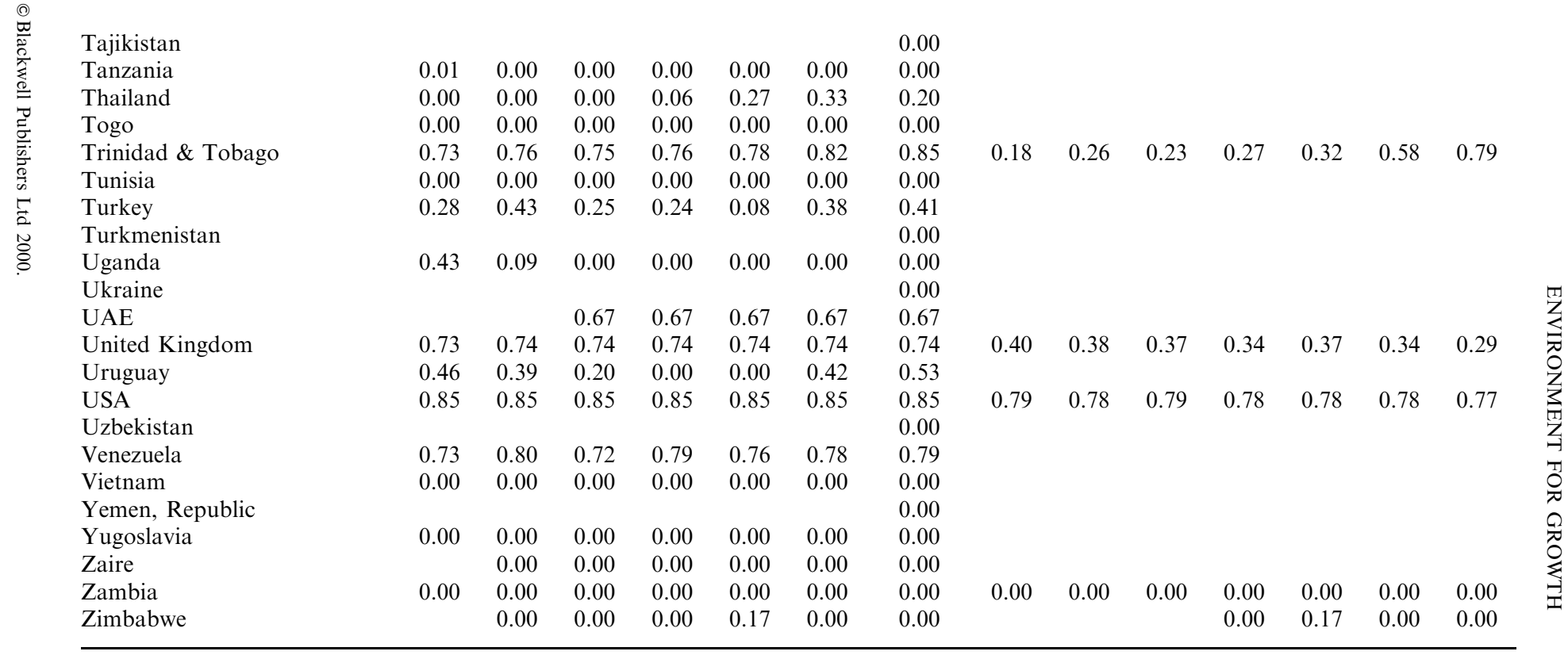

Note: Annual data for all countries up to and including 1998 is available from http://www-management.wharton.upenn.edu/henisz/ 

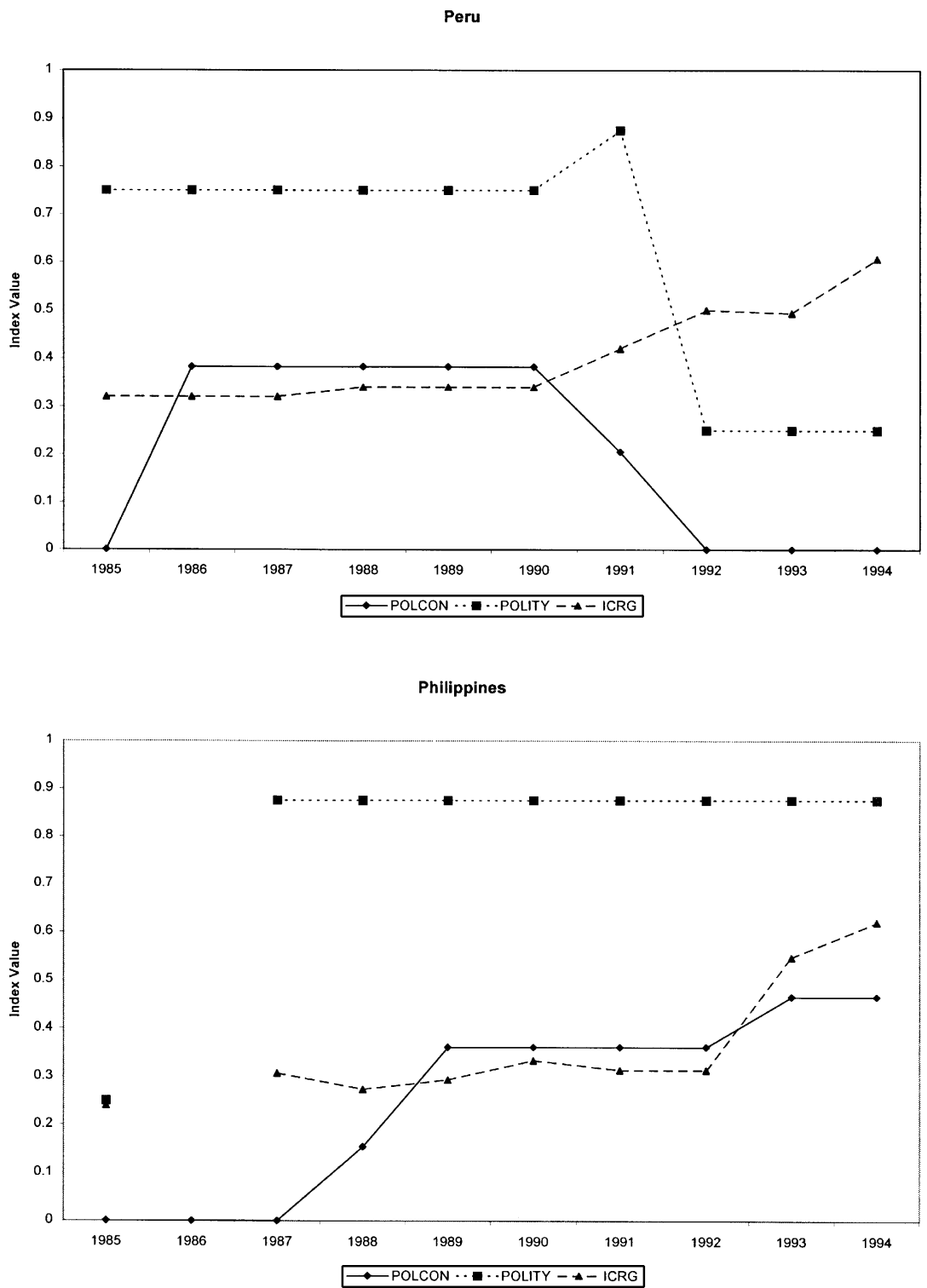


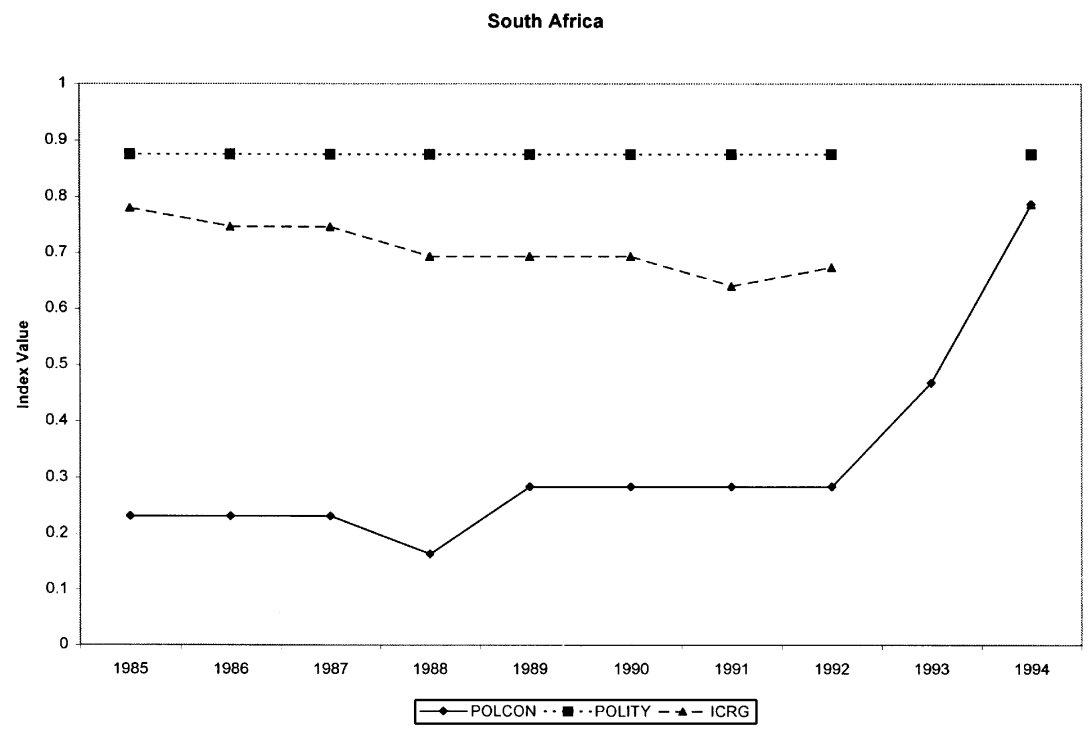

South Korea

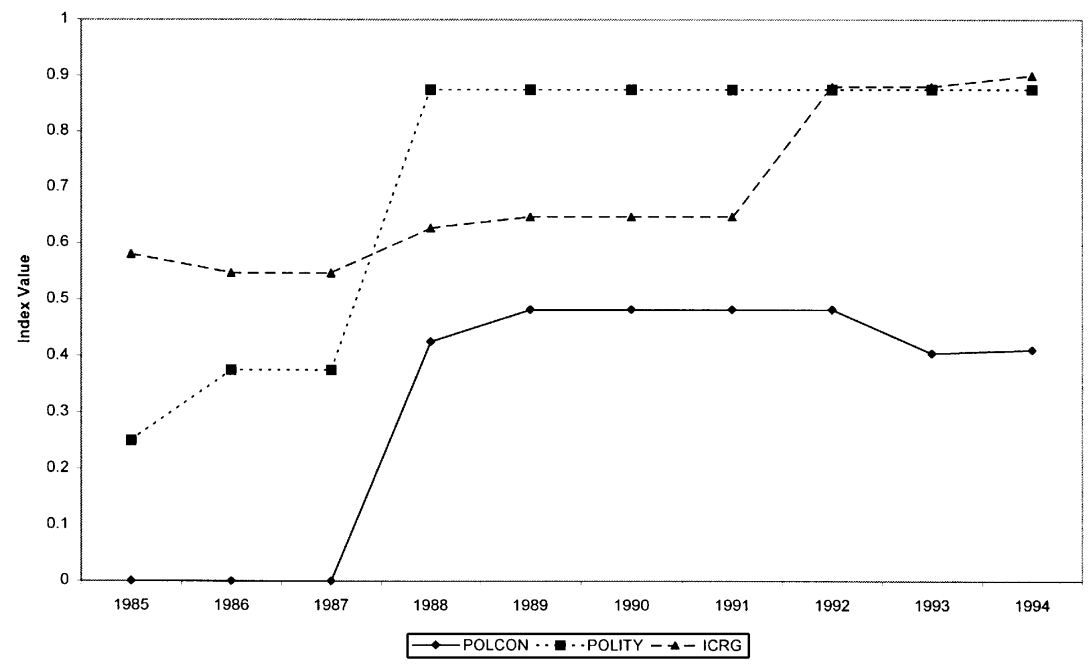

Figure 2. Political hazards in countries undergoing institutional change. 
and environmental variables that must be held constant to uncover this convergence effect. ${ }^{10}$

More formally, the underlying theoretical model presented by Solow (1956) and Koopmans (1965) yields a steady-state level of per capita output for a given set of choice and environmental variables. Should individuals in the economy or the government make choices which enhance the long-run steady-state level of per capita output (or should environmental shocks occur), output levels converge to their new steady-state over an extended transition period. This implies that growth rates in a given year will depend on the levels of individual and government choice variables as well as environmental variables. Furthermore, based on the assumption of diminishing marginal returns to capital, holding choice and environmental variables constant, countries with lower initial levels of per capita output can be expected to experience more rapid economic growth. The model does not predict any simple correlation between growth rates and starting positions only between the growth rates, holding all other choice and environmental variables constant, and initial conditions.

Thus, economic growth is posited to be a function of initial GDP and a set of control variables. These control variables include proxies for human and physical capital accumulation (as the quantity of factors available for production increases, growth is expected to increase) such as schooling, life expectancy, fertility and investment/GDP. Additionally, environmental, economic, political or institutional variables that are thought to affect the rate of return realized by the factors of production are also included in the analysis. Common variables expected to augment $(+)$ or distort $(-)$ the economic returns on human or physical capital include favorable terms of trade shocks $(+)$, government consumption exclusive of defense and education (-), the black market premium on foreign exchange (-), and indexes capturing either the extent of the rule of law, political stability, democracy or the degree of political constraints $(+)$. Changes in any of these control variables would be expected to alter the steady-state level of per capita output and lead to a lengthy transition period of positive/negative growth until that new steady-state level obtains. Vectors of regional and time period dummies are also commonly included in the analysis. See Table 3 for a description of the variables used in the econometric analysis that follows, along with their summary statistics.

\subsection{Estimation}

Results will be computed using OLS, GLS and GMM estimation techniques to insure maximum comparability with the extant literature and demonstrate robustness to alternative estimation techniques. It should be noted that while the GMM results are the most defensible from an econometric perspective (eliminating both the endogeneity problems addressed by GLS and the omitted

\footnotetext{
${ }^{10}$ The following discussion summarizes the literature overview provided by Barro (1996).
} 
Table 3 Summary Statistics for Variables InCluded in Regressions

\begin{tabular}{|c|c|c|c|c|c|c|}
\hline & $N(\max )$ & Mean & Median & Maximum & Minimum & Std. dev. \\
\hline Real Per Capita GDP Growth & 126 & 0.02 & 0.02 & 0.10 & -0.10 & 0.03 \\
\hline Log(Lagged Per Capita Real GDP) & 137 & 7.61 & 7.56 & 9.52 & 5.65 & 1.00 \\
\hline Male Secondary Education (years) & 107 & 1.22 & 0.93 & 4.81 & 0.03 & 1.01 \\
\hline Female Secondary Education (years) & 107 & 0.91 & 0.65 & 4.92 & 0.01 & 0.94 \\
\hline Log(Life Expectancy) & 118 & 4.03 & 4.03 & 4.32 & 3.55 & 0.21 \\
\hline $\log ($ Fertility Rate $)$ & 113 & 1.53 & 1.72 & 2.08 & 0.48 & 0.46 \\
\hline Government Consumption (\% GDP) & 137 & 0.11 & 0.10 & 0.40 & 0.00 & 0.08 \\
\hline Log(Black Market Exchange Rate Premium) & 127 & 0.24 & 0.08 & 2.02 & 0.00 & 0.39 \\
\hline Change in the Terms of Trade & 118 & 0.00 & -0.01 & 0.12 & -0.17 & 0.05 \\
\hline Total Investment (\% GDP) & 136 & 0.18 & 0.17 & 0.42 & 0.01 & 0.10 \\
\hline Log(Law \& Order Index $)$ & 111 & 0.84 & 0.80 & 1.70 & 0.15 & 0.45 \\
\hline No. Changes in the Identity of the Executive & 122 & 0.88 & 0.66 & 6.46 & 0.00 & 1.18 \\
\hline Democracy Index & 137 & 0.52 & 0.45 & 1.00 & 0.03 & 0.34 \\
\hline Political Constraint Index (POLCON) & 121 & 0.25 & 0.00 & 0.88 & 0.00 & 0.33 \\
\hline Political Constraint Index (POLCONJ) & 44 & 0.29 & 0.26 & 0.80 & 0.00 & 0.27 \\
\hline
\end{tabular}

Notes: All data from Barro and Lee (1994) except Law \& Order Index (International Country Risk Guide), No. Changes in the Identity of the Executive (Gurr, 1996), Democracy Index (Gurr, 1996, and Bollen, 1990) and Political Constraint Indexes (this paper). 
variable problem neglected therein), the extreme sensitivity of the coefficient estimate magnitudes and signs to specification has led to controversial economic interpretations.

\subsection{Results}

Table 4 closely mirrors the presentation of results reported in Barro (1996) but also presents alternative measures of the institutional environment. Column (1) uses the control variables proposed by Barro (1996) in an OLS regression. Columns (2) through (5) replace the rule-of-law index with the alternative measures of the institutional environment of number of changes in identity of executive, the democracy index used by Barro (1996), POLCON and POLCONJ. Columns (6) through (10) pursue the same strategy using 3SLS on five-year panels. Columns (11) to (12) repeat the process using the GMM specification of Caselli et al. (1996). All control variables yielded results similar to the extant literature. ${ }^{11}$

Of the political variables, a country increasing its 1985-1990 ICRG rating by one standard deviation (from the level of Argentina, Mexico or Egypt to that of Ireland, Taiwan or Botswana) could expect, ceteris paribus, approximately a 1.3 annual percentage point increase in growth rates (equal to $39 \%$ of one standard deviation). Executive turnover has no significant impact on growth rates using OLS or GLS but did have a statistically significant negative relationship (though small in economic significance) using GMM. As Barro (1996) demonstrates, ${ }^{12}$ a non-linear relationship between democracy and growth is suggested.

Turning to the variables derived in this paper, the results suggest that, ceteris paribus, a one standard deviation increase in POLCON (from an average level such as El Salvador or Sierra Leone to one equal to that of Taiwan, Madagascar or Singapore) would increase growth by 0.9 (OLS), 0.8 (GMM) or 0.5 (GLS) percentage points per year (equal to $31 \%, 25 \%$ and $17 \%$ of one standard deviation). A similar increase in POLCONJ (from the level of Botswana or Pakistan to that of Malaysia or Chile) would increase annual growth rates by 0.5 percentage points (GLS estimation). It should be noted that the gross effect of political constraints on economic growth is bounded by this estimate from below as countries with strong political institutions likely also possess good human and physical capital as well as fewer distortions in the financial markets.

For the sake of comparison, Table 5 presents the economic significance of all of the independent variables included in the analysis. Specifically, it lists (by econometric specification) the expected impact of a one-standard deviation

\footnotetext{
${ }^{11}$ The statistical and economic significance of these control variables have been the subject of innumerable articles and dissertations. The results here conform to the extant literature. Interested readers are referred to Barro (1996) for a recent and thorough description of the complete results.

12 "In the worst dictatorships, an increase in political rights might be growth enhancing because of the benefit from the limitations on government power. But in places that have already achieved a moderate amount of democracy, a further increase in political rights might impair growth because of the intensified concern with income redistribution" (Barro, 1996, p. 4).
} 
change in each independent variable on the dependent variable of economic growth both in percentage point terms and as a percentage of one standard deviation of the independent variable. ${ }^{13}$ While the effect on per capita economic growth of a one-standard deviation change in political constraints is small relative to the impact of a change of the same magnitude in initial conditions, the predicted improvement in per capita growth obtained by such an improvement in the institutional environment is comparable to a one-standard deviation increase in life-expectancy or the terms of trade or a one-standard deviation decrease in fertility rates, government consumption (exclusive of defense and education) or the black-market premium on foreign exchange. In short, the structurally derived internationally comparable measure of the institutional environment's ability to credibly commit to a given policy merits inclusion in studies of determinants of cross-national and intertemporal variation in economic growth.

\section{CONCLUSION}

While the estimated effect of the structurally-derived measure of political constraints are not as great or statistically significant as the country risk indexes conventionally used, it is important to keep the results in perspective. First, these risk indexes are not measured as a time series but as a point estimate at the end of the sample period thus aggravating any endogeneity problem. Second, the indexes are subjective measures that likely capture other relevant determinants of economic growth other than political institutions.

While the economic impact of political institutions is generally accepted, economists, private investors and policy-makers are only beginning to unpack the question of which political institutions matter; how they affect macroeconomic outcomes; and how they influence business decisions. By demonstrating that a structurally-derived measure of the feasibility of policy change is a significant predictor of cross-national variation in economic growth, this paper contributes to the transition of the empirical macro-political economy literature from macro-macro (using existing political science measures to predict national variation in macroeconomic outcomes) to micro-micro (identifying and measuring the economic impact of specific constellations of political institutions and preferences at an industry, firm or transaction level).

The spatial modelling framework used to make this transition may usefully be extended in a number of directions. First, regulatory bodies can be included as additional veto points in such sectors as telecommunications, electricity, or in industries characterized by substantial environmental concern. Second, the electoral rules that lead to the selection of the political actors within each veto

\footnotetext{
${ }^{13}$ The results presented are derived from the specifications using the political constraint measure derived in this paper [Columns (4), (9) and (11)].
} 
TABle 4 Political Institutions And Growth ${ }^{\mathrm{a}, \mathrm{b}, \mathrm{c}}$

\begin{tabular}{|c|c|c|c|c|c|c|c|c|c|c|c|c|}
\hline & (1) & $(2)$ & (3) & (4) & (5) & (6) & (7) & (8) & (9) & (10) & (11) & (12) \\
\hline Method & OLS & OLS & OLS & OLS & OLS & GLS & GLS & GLS & GLS & GLS & GMM & GMM \\
\hline$N$ & 79 & 84 & 84 & 82 & 44 & $66-83$ & $68-85$ & $67-87$ & $64-88$ & $30-39$ & $64-71$ & $64-71$ \\
\hline$T$ & '65-90 & '65-90 & '65-90 & '65-90 & '65-90 & \multicolumn{5}{|c|}{$\begin{array}{c}\text { [Five-Year Panels } \\
\text { 1960-1990] }\end{array}$} & \multicolumn{2}{|c|}{$\begin{array}{c}\text { [Five-Year Panels } \\
\text { 1965-1990] }\end{array}$} \\
\hline Initial GDP & $\begin{array}{l}-0.022^{* * *} \\
(0.004)\end{array}$ & $\begin{array}{l}-0.018^{* * *} \\
(0.003)\end{array}$ & $\begin{array}{l}-0.020^{* * *} \\
(0.003)\end{array}$ & $\begin{array}{l}-0.022 * * * \\
(0.003)\end{array}$ & $\begin{array}{l}-0.013^{*} \\
(0.006)\end{array}$ & $\begin{array}{l}-0.032 * * * \\
(0.004)\end{array}$ & $\begin{array}{l}-0.027 * * * \\
(0.004)\end{array}$ & $\begin{array}{l}-0.025^{* * *} \\
(0.004)\end{array}$ & $\begin{array}{l}-0.028^{* * *} \\
(0.004)\end{array}$ & $\begin{array}{l}-0.011^{*} \\
(0.005)\end{array}$ & $\begin{array}{l}-0.150 * * * \\
(0.001)\end{array}$ & $\begin{array}{l}-0.107^{* * *} \\
(0.002)\end{array}$ \\
\hline Male Education & $\begin{array}{l}0.009 \\
(0.005)\end{array}$ & $\begin{array}{l}0.008 \\
(0.006)\end{array}$ & $\begin{array}{l}0.007 \\
(0.006)\end{array}$ & $\begin{array}{l}0.010 \\
(0.005)\end{array}$ & $\begin{array}{l}0.003 \\
(0.009)\end{array}$ & $\begin{array}{l}0.013^{* *} \\
(0.005)\end{array}$ & $\begin{array}{l}0.009 \\
(0.005)\end{array}$ & $\begin{array}{l}0.008 \\
(0.004)\end{array}$ & $\begin{array}{l}0.011^{*} \\
(0.005)\end{array}$ & $\begin{array}{l}0.010 \\
(0.007)\end{array}$ & $\begin{array}{l}0.005 * * * \\
(0.001)\end{array}$ & $\begin{array}{l}0.013 * * * \\
(0.002)\end{array}$ \\
\hline Female Education & $\begin{array}{l}-0.011 \\
(0.006)\end{array}$ & $\begin{array}{l}-0.011 \\
(0.008)\end{array}$ & $\begin{array}{l}-0.010 \\
(0.008)\end{array}$ & $\begin{array}{l}-0.011 \\
(0.006)\end{array}$ & $\begin{array}{l}-0.003 \\
(0.009)\end{array}$ & $\begin{array}{l}-0.010 \\
(0.006)\end{array}$ & $\begin{array}{l}-0.006 \\
(0.006)\end{array}$ & $\begin{array}{l}-0.004 \\
(0.005)\end{array}$ & $\begin{array}{l}-0.008 \\
(0.007)\end{array}$ & $\begin{array}{l}-0.021^{* *} \\
(0.007)\end{array}$ & $\begin{array}{l}0.013 * * * \\
(0.002)\end{array}$ & $\begin{array}{l}0.019 * * * \\
(0.002)\end{array}$ \\
\hline Life Expectancy & $\begin{array}{l}0.032 * \\
(0.015)\end{array}$ & $\begin{array}{l}0.032 * \\
(0.016)\end{array}$ & $\begin{array}{l}0.030^{*} \\
(0.014)\end{array}$ & $\begin{array}{l}0.032 * \\
(0.013)\end{array}$ & $\begin{array}{l}0.016 \\
(0.029)\end{array}$ & $\begin{array}{l}0.048^{* *} \\
(0.016)\end{array}$ & $\begin{array}{l}0.068^{* * *} \\
(0.019)\end{array}$ & $\begin{array}{l}0.074 * * * \\
(0.018)\end{array}$ & $\begin{array}{l}0.065^{* * * *} \\
(0.019)\end{array}$ & $\begin{array}{l}0.063^{* * * *} \\
(0.019)\end{array}$ & & \\
\hline $\begin{array}{l}\text { Initial GDP* } \\
\text { Human Capital }\end{array}$ & $\begin{array}{l}-1.28^{*} \\
(0.54)\end{array}$ & $\begin{array}{l}-1.26 \\
(0.653)\end{array}$ & $\begin{array}{l}-1.37 \\
(0.716)\end{array}$ & $\begin{array}{l}-1.32^{*} \\
(0.536)\end{array}$ & $\begin{array}{l}-3.48 \\
(7.12)\end{array}$ & $\begin{array}{l}-0.399^{*} \\
(0.176)\end{array}$ & $\begin{array}{l}-0.310 \\
(0.178)\end{array}$ & $\begin{array}{l}-0.220 \\
(0.150)\end{array}$ & $\begin{array}{l}-0.406^{*} \\
(0.195)\end{array}$ & $\begin{array}{l}-0.507 * * * \\
(0.111)\end{array}$ & & \\
\hline Fertility & $\begin{array}{l}-0.018^{*} \\
(0.007)\end{array}$ & $\begin{array}{l}-0.020^{*} \\
(0.008)\end{array}$ & $\begin{array}{l}-0.019 * \\
(0.008)\end{array}$ & $\begin{array}{l}-0.017 * \\
(0.007)\end{array}$ & $\begin{array}{l}-0.017 \\
(0.012)\end{array}$ & $\begin{array}{l}-0.014^{*} \\
(0.006)\end{array}$ & $\begin{array}{l}-0.015^{*} \\
(0.006)\end{array}$ & $\begin{array}{l}-0.009 \\
(0.006)\end{array}$ & $\begin{array}{l}-0.016^{*} \\
(0.007)\end{array}$ & $\begin{array}{l}-0.007 \\
(0.009)\end{array}$ & $\begin{array}{l}0.007 * * * \\
(0.002)\end{array}$ & $\begin{array}{l}0.010 \\
(0.005)\end{array}$ \\
\hline $\begin{array}{l}\text { Government } \\
\text { Consumption }\end{array}$ & $\begin{array}{l}-0.041 \\
(0.033)\end{array}$ & $\begin{array}{l}-0.047 \\
(0.034)\end{array}$ & $\begin{array}{l}-0.058 \\
(0.030)\end{array}$ & $\begin{array}{l}-0.062 \\
(0.035)\end{array}$ & $\begin{array}{l}-0.140^{* *} \\
(0.048)\end{array}$ & $\begin{array}{l}-0.071^{* *} \\
(0.028)\end{array}$ & $\begin{array}{l}-0.069^{*} \\
(0.030)\end{array}$ & $\begin{array}{l}-0.063^{*} \\
(0.028)\end{array}$ & $\begin{array}{l}-0.074^{*} \\
(0.030)\end{array}$ & $\begin{array}{l}-0.085^{*} \\
(0.039)\end{array}$ & $\begin{array}{l}0.247 * * * \\
(0.030)\end{array}$ & $\begin{array}{l}0.718 * * * \\
(0.012)\end{array}$ \\
\hline $\begin{array}{l}\text { Black Market } \\
\text { Premium }\end{array}$ & $\begin{array}{l}-0.015^{* * *} \\
(0.004)\end{array}$ & $\begin{array}{l}-0.018^{* * *} \\
(0.005)\end{array}$ & $\begin{array}{l}-0.017 * * * \\
(0.004)\end{array}$ & $\begin{array}{l}-0.017 * * * \\
(0.004)\end{array}$ & $\begin{array}{l}-0.012 \\
(0.006)\end{array}$ & $\begin{array}{l}-0.025^{* * *} \\
(0.005)\end{array}$ & $\begin{array}{l}-0.026^{* * * *} \\
(0.006)\end{array}$ & $\begin{array}{l}-0.025^{* * *} \\
(0.005)\end{array}$ & $\begin{array}{l}-0.025^{* * *} \\
(0.005)\end{array}$ & $\begin{array}{l}-0.025^{* * *} \\
(0.007)\end{array}$ & $\begin{array}{l}-0.014^{* * *} \\
(0.001)\end{array}$ & $\begin{array}{l}-0.025^{* * *} \\
(0.001)\end{array}$ \\
\hline Terms of Trade & $\begin{array}{l}0.285^{* *} \\
(0.095)\end{array}$ & $\begin{array}{l}0.296 * * \\
(0.092)\end{array}$ & $\begin{array}{l}0.307 * * \\
(0.096)\end{array}$ & $\begin{array}{l}0.230^{*} \\
(0.105)\end{array}$ & $\begin{array}{l}0.489 * \\
(0.207)\end{array}$ & $\begin{array}{l}0.088 * * * \\
(0.022)\end{array}$ & $\begin{array}{l}0.087 * * * \\
(0.023)\end{array}$ & $\begin{array}{l}0.117 * * * \\
(0.022)\end{array}$ & $\begin{array}{l}0.086^{* * *} \\
(0.023)\end{array}$ & $\begin{array}{l}0.152 * * * \\
(0.035)\end{array}$ & $\begin{array}{l}0.074 * * * \\
(0.023)\end{array}$ & $\begin{array}{l}0.057 * * * \\
(0.004)\end{array}$ \\
\hline
\end{tabular}




\begin{tabular}{|c|c|c|c|c|c|c|c|c|c|c|c|c|}
\hline Investment & $\begin{array}{l}0.018 \\
(0.031)\end{array}$ & $\begin{array}{l}0.052 \\
(0.041)\end{array}$ & $\begin{array}{l}0.044 \\
(0.034)\end{array}$ & $\begin{array}{l}0.045 \\
(0.029)\end{array}$ & $\begin{array}{l}0.029 \\
(0.028)\end{array}$ & $\begin{array}{l}0.050^{*} \\
(0.023)\end{array}$ & $\begin{array}{l}0.029 \\
(0.024)\end{array}$ & $\begin{array}{l}0.030 \\
(0.023)\end{array}$ & $\begin{array}{l}0.034 \\
(0.024)\end{array}$ & $\begin{array}{l}0.060^{*} \\
(0.030)\end{array}$ & $\begin{array}{l}0.240^{* * * *} \\
(0.006)\end{array}$ & $\begin{array}{l}0.278^{* * * *} \\
(0.007)\end{array}$ \\
\hline Law \& Order & $\begin{array}{l}0.008^{* *} \\
(0.003)\end{array}$ & & & & & $\begin{array}{l}0.008 * * * \\
(0.002)\end{array}$ & & & & & & \\
\hline $\begin{array}{l}\text { Changes in } \\
\text { Executive }\end{array}$ & & $\begin{array}{l}0.001 \\
(0.001)\end{array}$ & & & & & $\begin{array}{l}-0.001 \\
(0.002)\end{array}$ & & & & $\begin{array}{l}-0.002 * * * \\
(0.000)\end{array}$ & \\
\hline Democracy & & & $\begin{array}{l}0.035 \\
(0.023)\end{array}$ & & & & & $\begin{array}{l}0.041 \\
(0.024)\end{array}$ & & & & \\
\hline Democracy $^{2}$ & & & $\begin{array}{l}-0.015 \\
(0.019)\end{array}$ & & & & & $\begin{array}{l}-0.038 \\
(0.023)\end{array}$ & & & & \\
\hline POLCON & & & & $\begin{array}{l}0.028^{* *} \\
(0.011)\end{array}$ & & & & & $\begin{array}{l}0.015^{*} \\
(0.007)\end{array}$ & & & $\begin{array}{l}0.023^{* * * *} \\
(0.004)\end{array}$ \\
\hline POLCONJ & & & & & $\begin{array}{l}0.008 \\
(0.014)\end{array}$ & & & & & $\begin{array}{l}0.019^{*} \\
(0.008)\end{array}$ & & \\
\hline$R^{2}$ (adjusted) & 0.73 & 0.69 & 0.72 & 0.77 & 0.69 & $\begin{array}{l}0.31,0.21 \\
0.37,0.26 \\
-0.06\end{array}$ & $\begin{array}{l}0.20,0.16 \\
0.27,0.25 \\
-0.02\end{array}$ & $\begin{array}{l}0.16,0.30 \\
0.28,0.25 \\
0.02\end{array}$ & $\begin{array}{l}0.21,0.16 \\
0.28,0.28 \\
0.02\end{array}$ & $\begin{array}{l}-0.13,-0.02 \\
-0.09,0.12 \\
-0.25\end{array}$ & $\begin{array}{l}0.30,0.48 \\
0.56,-0.08\end{array}$ & $\begin{array}{l}0.01,0.30, \\
0.30, \\
-0.37\end{array}$ \\
\hline
\end{tabular}

$a * * *$ and $* * *$, represent significance at $95 \%, 99 \%$ and $99.9 \%$ confidence intervals respectively; OLS coefficients computed using White heteroscedasticity consistent standard errors and covariances [see White (1980)]; regional and time dummy coefficients omitted (coefficients are jointly significant in each specification).

${ }^{b}$ Following Barro (1996), human capital is defined as the sum of the predicted effects of male and female secondary educational attainment, the log of life expectancy, and the log of fertility expressed as deviations from their mean levels. This interaction term allows the effect of the human capital variables and initial income to be non-linear. For example, the results obtained suggest that countries with relatively low levels of initial income converge to their long-run positions more rapidly if they possess relatively high levels of human capital.

${ }^{c}$ Values for each five-year period are reported in columns 6-12. 
Table 5 The Impact of a One-Standard Deviation Change in the IndePendent VARIABLES ON ECONOMIC GROWTH

\begin{tabular}{llll}
\hline & OLS & \multicolumn{1}{c}{ GLS } & \multicolumn{1}{c}{ GMM } \\
\hline Initial GDP & $-2.2 \%$ & $-2.8 \%$ & $-10.7 \%$ \\
& $(73.3 \%)$ & $(93.3 \%)$ & $(356.7 \%)$ \\
Male Education & not significant & $1.1 \%$ & $1.3 \%$ \\
& & $(37.0 \%)$ & $(43.8 \%)$ \\
Female Education & not significant & not significant & $1.8 \%$ \\
& & & $(59.5 \%)$ \\
Life Expectancy & $0.7 \%$ & $1.4 \%$ & $\mathrm{n} / \mathrm{a}$ \\
& $(22.2 \%)$ & $(45.5 \%)$ & \\
Fertility & not significant & $-0.7 \%$ & not significant \\
Government & & $(24.5 \%)$ & $5.7 \%$ \\
Consumption & not significant & $-0.6 \%$ & $(191.5 \%)$ \\
Black Market & & $(19.7 \%)$ & $-1.0 \%$ \\
Premium & $-0.7 \%$ & $-1.0 \%$ & $(32.5 \%)$ \\
Terms of Trade & $(22.5 \%)$ & $(32.5 \%)$ & $0.3 \%$ \\
Investment & $1.2 \%$ & $0.8 \%$ & $(9.5 \%)$ \\
POLCON & $(38.3 \%)$ & $(25.3 \%)$ & $2.8 \%$ \\
& not significant & not significant & $(92.7 \%)$ \\
& & & $\mathbf{0 . 8 \%}$ \\
\hline
\end{tabular}

Note: Values in parentheses are the percentage of a one-standard deviation change in the dependent variable caused by a one-standard deviation change in the independent variable.

point could be examined. For example, if the regulatory body is appointed by the executive subject to the confirmation of the upper chamber of the legislature, the spatial preferences of the regulatory body are delimited within the approval set of the executive and that legislative chamber. Similar analysis may be utilized to capture the likely preferences of judicial appointments over time. The extent to which the median preferences reflect national rather than narrow (particularistic) ${ }^{14}$ constituencies may also be analyzed so as to ascertain the relative magnitude of the dead weight loss associated with a given policy change. For example, in a highly particularistic polity, discretion may be relatively more costly making constraints relatively more tightly linked to economic outcomes. Relationships between the constraints, particularism and the susceptibility of a country to external shocks may also be included within this framework.

The analysis presented here thus offers not a definitive answer as to the nature of the link between political institutions and economic outcomes but preliminary

\footnotetext{
${ }^{14}$ See, in particular, the work of Ernesto Stein and Jessica Seddon.
} 
evidence for a new set of tools that should prove useful in unpacking precisely which institutions matter and how they affect specific economic outcomes. By demonstrating that a structurally derived internationally comparable measure of the feasibility of policy change performs as well as more commonly used measures of the political system in the vast macroeconomic growth literature, this paper has presented evidence in a macroeconomic setting for this type of analysis. The speculative extensions summarized above offer the potential to delve further into the microanalytics of the political process and ascertain the relative magnitude of these effects in countries that vary in the nature of their electoral rules and susceptibility to economic shocks. Altering the left-hand-side variable to examine the variability of specific policies, categories or classes of investment as well as the adoption of specific market and non-market strategies by host-country and multinational firms would similarly extend this microanalytic approach.

\section{APPENDIX 1: CONSTRUCTING POLCON AND POLCONJ}

\section{Data Sources}

Construction of a measure of political constraints based on the methodology described herein requires three types of data. First, information regarding the number of institutional players in a given polity; second, data on partisan alignments (including coalitions) across institutions; and, finally, data on the party composition of legislatures. All countries were assumed to have an executive. Data on the existence of other political actors (unicameral or bicameral legislatures ${ }^{15}$ and sub-federal units ${ }^{16}$ ) with substantive veto power was taken from the Polity database [see Gurr (1996)] and Derbyshire and Derbyshire (1996).

Unfortunately, no such time-series measure was available to measure judicial independence over time. Following Barro (1996), the average 1985-1990 value of $L A W \& O R D E R^{17}$ from the ICRG was used to compute a dummy variable (equal to 1 if $L A W \& O R D E R \geqslant 4$ ) regarding the extent of judicial independence in a given country over the entire sample. Unfortunately, law and order may be provided through a well-functioning legal system or through repressive policies.

\footnotetext{
${ }^{15}$ Effective legislatures possess "significant governmental autonomy . . . including, typically, substantial authority with regard to taxation and disbursement, and the power to override vetoes of legislation". A classification of partially effective is assigned when "the effective executive's power substantially outweighs but does not completely dominate that of the legislature" (Gurr, 1989, p. 51).

${ }^{16}$ While such sub-federal units will not have veto power over all relevant economic policies, the existence of such extensive delegation of economic authority implies that they will play a role in many key issues.

17 "A country with a sound law and order tradition has sound political institutions, a strong court system and provisions for an orderly succession of power. This indicator reflects the degree to which the citizens of the country are willing to accept the established institutions to make and implement laws and adjudicate disputes. A high point total means that there is a strong law and order tradition, while a low point total means that there is a tradition of depending on physical force or illegal means to setting claims" (International Country Risk Guide, 1996).
} 
In order to separate out the latter case, only those country-years in which the Polity database indicated at least "slight to moderate limitations to executive authority" existed were coded as having an independent judiciary. A sufficient but not necessary condition for this coding is the presence of an independent judiciary. While this process creates problems of endogeneity and subjectivity, efforts to develop a more objective measure of judicial independence based on judicial tenure or hazard rates have to date yielded results for less than half the sample. While preliminary results examining the correlation of judicial tenure with economic outcomes has been promising, using this measure would unduly restrict the sample size.

The above data sources were then supplemented by various issues of The Political Handbook of the World and The Statesman's Yearbook to note the party distribution of the legislature(s): specifically, whether the executive enjoys a majority in one (or both) legislature(s) and how many seats in each legislature were controlled by each party. Based on this information, the values of institutional hazards were modified to form a preliminary measure of political constraints (POLCON) using the methodology described in the previous section.

Finally, the identity of justices of the Supreme Court or highest court of appeal for private contractual disputes, during the period 1960-1996 was collected for a sample of 44 countries. ${ }^{18}$ The preliminary measures of political constraints were then further modified to take into account alignment between the court and the individual executive or the party of the individual executive ${ }^{19}$ as well as the polarization or fractionalization of the court. The final variable constructed was labelled POLCONJ.

\section{Sample Calculations}

In the United States in 1990 the lower and upper houses of the legislature were controlled by the Democratic Party while the Republican Party controlled the executive. Were the two legislative chambers completely controlled by separate opposition parties, the political constraint measure would equal $0.90(E, L 1, L 2, F, J=19 / 21)$. Were they completely controlled by a single opposition party, the political constraint measure would be 0.87 $(E, L, F, J=13 / 15)$. If the legislatures were completely aligned with the executive the measure would be $0.80(E, F, J=4 / 5)$. However, as the same opposition party controlled both legislatures and the fractionalization index

\footnotetext{
${ }^{18}$ Efforts to increase this sample are ongoing.

${ }^{19}$ Because of the lifetime (or long-term) tenure of Supreme Court justices, party alignment alone was not thought sufficient to indicate alignment as judicial preferences and the preferences of the appointing executive may diverge subsequent to appointment with few, if any, consequences. A higher standard for alignment was used to capture this important difference between judicial and legislative preferences over time. Specifically, courts were considered aligned when the current executive appointed the majority of justices of Supreme Court or for cases in which the party of the current executive appointed $2 / 3$ of justices.
} 
equalled 0.48 and 0.50 , the final value of political constraints (POLCON) equals $0.80+[((1-0.48) / 2+(1-0.50) / 2)) *(0.87-0.80)]=0.83$. Next, because more than two-thirds of the High Court was appointed by executives of the Republican Party, the judiciary is not treated as fully independent. Specifically, if the legislatures were completely aligned and there existed no independent court, the constraint score would equal 0.67 ( $E, L, F=2 / 3)$. Given the levels of fractionalization of the legislatures and the court the modified value of political constraints POLCONJ is equal to $0.67+[((1-0.48) / 3+(1-0.50) / 3+0.39 / 3) *(0.87-0.67)]=0.76$.

For New Zealand in 1990, the legislative chamber and the executive are jointly controlled by the Labour Party as is necessarily the case in Westminster-style democracies. ${ }^{20}$ The value of political constraints based on veto points alone of $0.80(E, L 1, J=4 / 5)$ must therefore be adjusted to reflect the lack of independence by the legislature. Without a legislature New Zealand's score would be $0.67(E, J=2 / 3)$ so the POLCON score given the fractionalization index of 0.49 is $0.67+0.49 *(0.80-0.67)=0.73$. If the legislatures were completely aligned and there existed no independent court the constraint score including judicial data (POLCONJ) would equal $0.00(E=0)$. Given the levels of fractionalization of the legislature (0.49) and the court (0.50) the modified value of POLCONJ is equal to $0.00+(0.49 / 2+(1-0.50) / 2) *(0.80-0.00)=0.40$.

Finally, in the case of Bolivia in 1990, both the upper and lower houses of the legislature are controlled by the same opposition party (The National Revolutionary Party) but they are highly fractionalized. The value of political constraints based on veto points alone of $0.80(E, L 1, L 2=4 / 5)$ must therefore be adjusted downward to capture the higher decision costs faced by the fractionalized opposition legislative chambers relative to a more homogeneous opposition. If the two houses were completely fragmented, the political constraint score would equal $0.00(E=0)$. However, the fractionalization indexes of 0.74 and 0.74 for the opposition legislatures yield a final score of $0.00+((1-0.74) / 2+(1-0.74) / 2) *(0.80-0.00)=0.21$. No data is available regarding the appointment history of the court so POLCONJ is left empty.

Now consider the case of Guyana prior to and following its 1993 election. In both periods Guyana has two veto points $(E, L 1)$ and thus has a maximum possible political constraint index value equal to 0.67. However, in 1990, the same party (the People's National Congress) controlled the presidency and held 42 of the 53 legislative seats, with the remaining seats distributed among three other parties. The fractionalization index equalled 0.35. As a result, POLCON equalled $0.00+0.35 *(0.67-0.00)=0.24$.

In 1993, Guyana held an election in which the People's Progress Party won the Presidency and the majority in the legislature. The new distribution of seats was

\footnotetext{
${ }^{20}$ Note that $P O L C O N$ and $P O L C O N J$ automatically yield lower scores for Westminster systems and higher rankings for mixed executive systems in which power is held by different parties.
} 
35 for the People's Progress and 27 for the People's National Party, with the remaining parties' seat totals unchanged. In this case, the fractionalization index increased to 0.55 , signifying that it was relatively more difficult for the new governing party to steamroll the legislature in comparison to their immediate predecessor (i.e., their majority was slightly more tenuous). The political constraint index value thus rose from 0.24 to $0.00+0.55^{*}(0.67-0.00)=0.37$.

\section{WITOLD J. HENISZ}

The Wharton School,

University of Pennsylvania

\section{REFERENCES}

Baron, D. P., 1998, Comparative dynamics of parliamentary governments. American Political Science Review 92, 593-610.

Barro, R., 1996, Democracy and growth. Journal of Economic Growth 1, 1-27. and J. W. Lee, 1994, Sources of economic growth. Carnegie-Rochester Conference Series on Public Policy 40, 1-46.

Bollen, K. A., 1990, Political democracy: conceptual and measurement traps. Studies in Comparative International Development 25, 7-24.

Borner, S., A. Brunetti and B. Weder, 1995, Political Credibility and Economic Development (St. Martin's Press, New York).

Campos, N. and J. Nugent, 1996, Institutions and economic growth in Latin America: an econometric study. Manuscript provided by Jeffrey Nugent.

Caselli, F., G. Esquivel and F. Lefort, 1996, Reopening the convergence debate: a new look at cross-country growth empirics. Journal of Economic Growth 1, 363-390.

Clague, C., et al., 1996, Property and contract rights under democracy and dictatorship. Journal of Economic Growth 1, 243-276.

Council on Foreign Relations (ed.), various, The Political Handbook of the World (McGraw-Hill, New York).

Derbyshire, J. D. and I. D. Derbyshire, 1996, Political Systems of the World (St. Martin's Press, New York).

Dornbusch, R., 1991, Policies to move from stabilization to growth. Proceedings of the 1990 World Bank Annual Conference on Development Economics, 19-48.

Durham, J. B., 1999, Economic growth and political regimes. Journal of Economic Growth $4,81-111$.

Gurr, T. R., 1989, Polity II Codebook (Center for Comparative Politics, Boulder, CO).

- 1996, Polity III: Political Structures and Regime Change, 1800-1994 [computer file]. Boulder, $\mathrm{CO}$, Center for Comparative Politics [producer], Inter-University Consortium for Political and Social Research [distributor].

International Country Risk Guide, various, Political and Financial Risk Tables (Political Risk Services Group, East Syracuse, NY).

Keefer, P. and S. Knack, 1997, Why don't poor countries catch up? A cross-national test of an institutional explanation. Economic Inquiry 35, 590-602.

Knack, S. and P. Keefer, 1995, Institutions and economic performance: cross-country tests using alternative institutional measures. Economics and Politics 7, 207-227.

Koopmans, T. C., 1965, Econometric Approach to Development Planning (North-Holland, Amsterdam).

La Porta, R., et al., 1997, Legal determinants of external finance. Journal of Finance 52, $1131-1150$. 
Levy, B. and P. Spiller, 1994, The institutional foundations of regulatory commitment: a comparative analysis of telecommunications regulation. Journal of Law, Economics and Organization 10, 201-246.

$\longrightarrow$ and - , eds., 1996, Regulations, Institutions and Commitment (Cambridge University Press, Cambridge).

Lucas, R., 1988, On the mechanisms of economic development. Journal of Monetary Economics 22, 3-42.

Mankiw, N. G., D. Romer and D. N. Weil, 1992, A contribution to the empirics of economic growth. Quarterly Journal of Economics 107, 407-437.

Mauro, P., 1995, Corruption, country risk and growth. Quarterly Journal of Economics $110,681-712$.

Moe, T. and M. Caldwell, 1994, The institutional foundations of democratic government: a comparison of presidential and parliamentary systems. Journal of Institutional and Theoretical Economics 150, 171-195.

Murphy, K. M., A. Shleifer and R. Vishny, 1991, The allocation of talent: implications for growth. Quarterly Journal of Economics 106, 503-530.

North, D. C., 1990, Institutions, Institutional Change and Economic Performance (W. W. Norton, New York).

- and R. P. Thomas, 1973, The Rise of the Western World: A New Economic History (Cambridge University Press, Cambridge).

Olson, M., 1996, Big bills left on the sidewalk: why some nations are rich and others poor. Journal of Economic Perspectives 10, 3-24.

Palmer, M., 1995, Toward an economics of comparative political organization: examining ministerial responsibility. Journal of Law, Economics and Organization 11, 164-188.

Paxton, J. (ed.), various, The Statesman's Yearbook (St. Martin's Press, New York).

Rae, D. W. and M. Taylor, 1970, The Analysis of Political Cleavages (Yale University Press, New Haven, CT).

Rice, J. A., 1995, Mathematical Statistics and Data Analysis (Duxbury Press, Belmont, CA).

Rodrik, D., 1992, Political economy and development policy. European Economic Review 36, 329-336.

, 1993, The positive economics of policy reform. American Economic Review 83, 356-361.

Sala-i-Martin, X., 1997, I just ran a million regressions. NBER Working Paper 6252.

Solow, R., 1956, A contribution to the theory of economic growth. Quarterly Journal of Economics 70.

Spiller, P. T. and E. H. Tiller, 1997, Decision costs and strategic design of administrative process and judicial review. The Journal of Legal Studies 26, 347-370.

- and I. Vogelsang, 1996, The institutional foundations of regulatory commitment in the UK (with special emphasis on telecommunication), in: B. Levy and P. T. Spiller, eds., Regulations, Institutions and Commitment (Cambridge University Press, Cambridge) 121-144.

Weingast, B., 1993, Constitutions as governance structures: the political foundations of secure markets. Journal of Institutional and Theoretical Economics 149, 286-311.

White, H., 1980, A heteroscedasticity-consistent covariance matrix estimator and a direct test for heteroscedasticity. Econometrica 48, 817-838.

World Bank, 1997, The State in a Changing World (Oxford University Press, New York). 